\title{
From Urban Enclave to Ethnoburb: Discourse, Space, and Community in Polish Chicago
}

\author{
Jason Schneider
}

In this paper I want to tell a story of discourse, space, and community —or more specifically, a story of how discourse and space can intersect with a community's efforts to construct its own identity. The community that interests me is the Polish immigrant community in Chicago, which is the center of my ethnographic research. By telling the story of how Chicago Poles have moved among urban neighborhoods and suburban areas over the last 150 years or so, and by drawing on research participants' ways of talking about the present-day spaces of metropolitan Chicago, I want to look at how these collective movements and discourses overlap with the community's shifting ideologies and aspirations. Also, by drawing on the idea of the "ethnoburb," a term geographer Wei Li uses to describe the emerging phenomenon of suburban areas where many ethnic groups live together, I aim to show how Chicago Poles' recent settlement patterns mirror larger demographic trends. But I also want to use this specific site to develop a broader theoretical understanding of the relationship between discourse and space. In short, my argument is that discourse and space are mutually productive and constitutive forces, such that our experience of space is deeply discursive and our discursive inventions are deeply embedded in spatial experience. Even more, I want to show not only how space interlinks with discourse, and implicitly ideology, but also how it actively partici- 
pates in discourse as a signifier. My method for developing this argument relies on a combination of theoretical insights from fields such as spatial theory, urban planning, and rhetorical studies; evidence from historical writings about both Chicago and Poland; and data from my fieldwork among Polish immigrants in and around Chicago. It is this "grounded" evidence-which emerges from nearly two years of participant observation and extensive interviews with several Chicago Poles-that provides the real foundation of my argument, because, in my view, the analysis of everyday practices and ways of talk offers an exceptionally rich method for understanding the relationship between space and discourse. In my case, these are the practices of a specific group of immigrants in a specific place, and in the second half of the paper I will examine some of the ways in which Poles' unique political and social histories have influenced their discourses. However, the processes I will explore operate among many other groups, including other immigrant groups in the U.S., and the theoretical implications are much broader.

As a way into those broader claims, I want to start at the level of ethnographic observation, by offering two brief vignettes from my fieldwork that I think help encapsulate, in miniature, the larger points I am trying to develop. Both scenes involve maps — our most pervasive and stylized discourse of space—and both scenes take place in a small room in the basement of a Polish church on Chicago's northwest side. As a central aspect of my fieldwork from 2010-2012, I participated in a grassroots Polish immigrant rights organization, whose weekly meetings took place in the church basement. ${ }^{1}$ This meeting space was used by the group for the first few years of its existence, and it was attractive primarily because it was free (one of the members was a parishioner). But the location was also agreeable, since the church was in the heavily Polish neighborhood of Portage Park, where some group members lived; also, it was easily accessible from the I-90 Kennedy Expressway, which connected to the northwest suburban homes of some other group members. The organization has grown since those times and now has its own space inside the building of a major Polish-American cultural institution. However, for that first period of development, the church basement provided a conducive setting for regular Wednesday-evening planning sessions, which were, from my perspective, events of inspiring camaraderie-but also very intimate, intense affairs that sometimes included heated debates and, on occasion, raw emotional displays.

\section{Map Scene 1: Polish Highways and Byways}

On one particular Wednesday, as the meeting was about to begin, one of the group's founding members, Magda, put a large, hard-cover book on the table: Polish Highways and Byways. It was a colorful road atlas, which, for reasons not worth explaining, the group had received as a gift. For that week's "ice breaker," Magda proposed that each of the ten or so people in attendance find the number of the "highway" closest to his or her home in Poland. But before anyone could begin, Magda wondered aloud, "Hey, wait-'Polish Highways.' Why is it such a big book? It should have like three pages.” The room fell apart in laughter. The lack of a national highway system in Poland has been a point of on-going debate and anger 
since at least the 1990s, with the public growing increasingly bitter about the lack of progress since Poland joined the E.U. in 2004, which was supposed to open up funds for infrastructure projects, but which has resulted in the completion of only a fraction of the 2,000 kilometers of planned limited access highways, due at least partly to political wrangling. This joke led to a string of wisecracks about the roads in Poland and to some speculation about what the publishers of the atlas might have had in mind when they titled the book. In the end, though, everyone followed Magda's directions, taking a minute to scan the book in search of the "highway"-in some cases just a two-lane road-closest to his or her Polish home. Gabriel announced that he lived near Highway 79. Magda said she lived near 46. Everyone else noted the place of his or her home. Through this entire process - which involved much more laughter, as a new thread of jokes about Polish infrastructure seemed to spin out at every turn - the atlas transformed into something much more than a two-dimensional representational of Polish roads. Rather, it became a kind of ideological-rhetorical compass for the group members, as it stood in for the thing that bound them all together: "Poland" and "Polishness," and, perhaps more to the point, their shared experiences of bumpy roads, political paralysis, and myriad other everyday frustrations of living in a communist or post-communist country. Additionally, the book and its discourse on distant geographies stood in for the political desire that had brought everyone together on that evening, as on so many other evenings - a desire to positively affect the situations of Poles and other immigrants both in Chicago and across the U.S.

\section{Map Scene 2: The $38^{\text {th }}$ Ward}

On another Wednesday evening, in the fall of 2010, the group was gearing up for a door-knocking campaign - this time to encourage Polish immigrants to vote in the upcoming elections for local, state, and federal offices. The group had been engaged in a voter-registration campaign throughout the summer, registering several hundred Polish voters, and now it was time to try to get them to the polls, with the hope that they would vote for candidates who had pledged to support pro-immigrant initiatives. Michalina, another founding member of the group, pulled out a thickly folded piece of paper, a map of Chicago's $38^{\text {th }}$ Ward (Fig. 1). As she laid it on the table before her, we could all see the streets surrounding the church and beyond. Since the $38^{\text {th }}$ Ward included much of the Portage Park neighborhood, the area of Chicago that has the strongest concentration of Polish immigrants, everyone knew that many of these streets were lined with Polish homes. As we crowded around the map, the discussion turned to blocks where members had carried out door-knocking before, and where there were known to be heavy concentrations of Poles. Then, slowly, specific plans began to take shape: Who could join a group of door-knockers next Monday evening? Next Tuesday? What would be the goal for the next two weeks? As all of this developed—and soon someone was making a sign-up sheet of days and times - the map took on a significance far beyond the streets, buildings, and parks of the $38^{\text {th }}$ Ward. Like the Polish Highways and Byways 
atlas, the ward map came to stand in for, and even participate in, the group's discourses of activist collaboration and its shared ideal of a politically powerful Chicago Polish community. For those moments, the " $38^{\text {th }}$ Ward" was more than a collection of city blocks, represented by a horizontally elongated black-and-white design; rather, it was a geographical-material phenomenon that signified political possibility. In this way, the map, and the ensuing discussion, highlighted how the spatial, rhetorical, and ideological realms can intersect and overlap as part of everyday life.

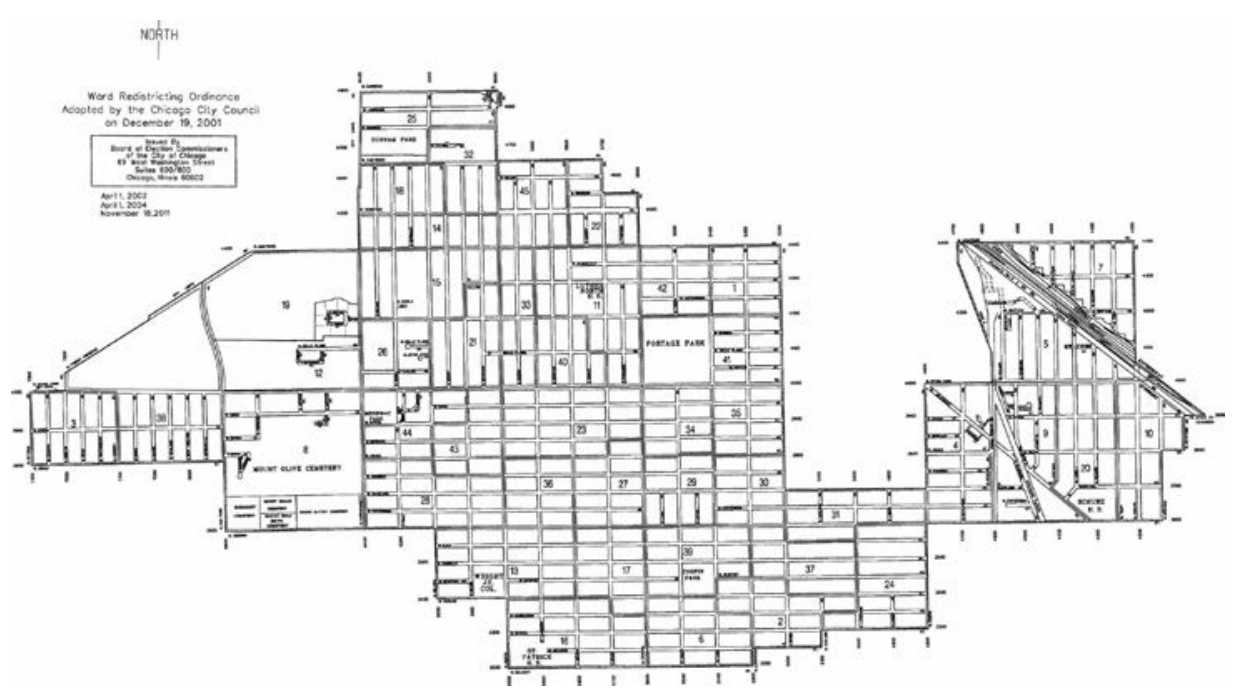

Figure 1 - Official map of Chicago's 38th Ward

\section{Discourse, Space, and Community}

Before I extend these heuristics to the larger story of the Chicago Polish immigrant community's discourses and spaces, I want to give some context for my theoretical perspective. In short, I, like many others in the humanities and social sciences, have been influenced by the insights of spatial theorists such as Henri Lefebvre, Edward Soja, David Harvey, and Manuel Castells. Perhaps most simply, their shared assumption that space itself is a foundational force in the construction of social, political, economic experience is profoundly convincing. Or, as Barney Warf and Santa Arias put it in their description of why spatial thought is gaining popularity across the disciplines, "[g]eography matters, not for the simplistic and overly used reason that everything happens in space, but because where things happen is critical to knowing how and why they happen” (1). In terms of discourse and cultural studies, this statement suggests a kind of hermeneutical imperative: If we want to understand cultural artifacts, we must also understand the spatial phenomena surrounding the creation and dissemination of those artifacts. In a sense, this is one more call to consider the contexts of invention. ${ }^{2}$ That is, just as cultural, 
literary, and critical theorists of recent decades have emphasized how social, economic, and historical factors shape the production of texts-and, moreover, our readings of those texts - the spatial perspective introduces one more such factor into the equation. In the case of rhetoric and communications studies, in particular, there has been a growing body of work that takes up this call to consider the role of space. In recent years, for example, Greg Dickinson has contemplated the intersections of space, memory, and consumerist subjectivities in his analyses of everyday sites, including those of downtown Old Pasadena ("Memories of Sale”) and a Starbucks coffee shop (“Joe's Rhetoric”); Dickinson, Blair, and Ott, among others, have examined the relationship between discourse and public memorial sites; Jordynn Jack has written about the differentiated spaces of everyday life in and around the Los Alamos laboratory, and the resulting memory rhetorics that encapsulate ideologies of science and gender; Elizabeth Ada Wright has explored cemetery spaces, which, in her view, allow for the production of rhetorics that have historically been treated as inappropriate for more prestigious public spaces, namely rhetorics that memorialize women, and specifically African-American women; and David Fleming has persuasively argued that the socioeconomically divided spaces of contemporary American life, and our most pervasive modes of urban planning, hinder the possibility for democratic rhetorics. The work of these and other critics offers valuable insights on the intersection of space and rhetoric. In a sense, they extend spatial theory's central claim that “...space itself must be considered as one element of the productive forces of society" (Gottdiener 123) by interrogating the implications of that claim at specific sites of discourse.

I too accept that space is one of the "productive forces of society," and I concur with the above scholars who interpret space as a productive force for discourse. However, my analysis of Polish Chicago seeks to do more than simply highlight how spatial phenomena have influenced the invention of Polish immigrant rhetorics; I also want to explore how space and discourse interact with and mutually constitute one another in the world of Polish Chicago, and, moreover, how space itself has become an active participant in everyday rhetorics. To some extent, this involves inverting the claim that space shapes discourse by also claiming that discourse shapes space. As I see it, this is a direct extension of Lefebvre's observation that space is a product of social configurations, and that "what we call ideology only achieves consistency by intervening in social space and in its production" (44). For cultural theorists, Lefebvre's "ideology" is deeply intertwined with "discourse," and, thus, we can argue that discourse can only "achieve consistency" by "intervening" into the production of space.

One example of how this process might look comes from Cezar Ornatowski's writing on rhetoric, architecture, and political ideology in the reconstruction of postWorld War II Warsaw. As Ornatowski describes it, the "spatial arrangements" of communist Poland, by which he means both architectural features and urban planning, were explicit efforts to embody a set of ideological principles, and, to this end, were the material manifestations of a very specific political discourse. To emphasize this discursive dimension, Ornatowski looks at an influential 1949 
address by the first leader of the People's Republic of Poland, Bolesław Bierut, called "The 6-Year Plan for the Reconstruction of Warsaw." In the speech, Bierut outlined the principles by which the Polish capital, much of which had been razed by Nazis, should be rebuilt. Included in his vision were calls for a "new content and new external form and architectural expression clear and understandable to the broad masses of workers and peasants in Poland," and for a model city that would "lay the foundations for the transformation of life on socialist principles" (qtd. in Ornatowski 215). For Ornatowski, the importance of Bierut's address is that it "figures forth" a new social world by way of a "triple thrust": 1) it "bodies forth ... a brick-andmortar world for people to inhabit"; 2) it "endows it with ideological content and renders it ideologically legible"; and 3) it makes the new urban form a "figure" of the state (215). In effect, Ornatowski's claim that the built world of post-war Poland embodied the ideology of the communist state highlights how discourse can shape space. However, he goes one step further, by also observing that the spaces of Warsaw themselves became signifiers in another discourse, which, in turn, helped "figure forth" the broader world of socialist Poland. That is, by the 1950s, reconstructed Warsaw had become a prominent symbol of "the new socialist, collective identity," serving as "a showcase space to which children and workers were brought from around the country; a place about which songs were sung and that (according to a popular slogan) the 'entire nation [was] engaged in building"” (216). Thus, the space of post-World War II Warsaw emerged as a result of the rhetorics of a new politics, and then the space itself became a powerful participant in the discourse of that same politics.

These ideas inform my understanding of Polish immigrants' interactions with the spaces of Chicago. As this community has inhabited particular urban spaces, and shaped those spaces - in some cases very literally, through building and design, and in other cases more metaphorically, by establishing "Polish" areas of the city and the suburbs - there has been an on-going relationship of mutual production and constitution between discourse and space. Moreover, space itself has become a participant in the everyday community rhetorics of Chicago Poles, such that certain spaces are signifiers in the community's shifting discourses of identity. To borrow Kenneth Burke's articulation of metonymy, the rhetorical figure by which one term stands in for a closely related term, I might put it this way: in Polish Chicago, space operates as a "reduction" that conveys "some incorporeal or intangible state in terms of the corporeal or tangible" (506). This is the process by which spaces take on specific meanings for specific audiences. But those spaces, as meanings, then get mobilized rhetorically, as what Burke calls "metaphorical extension[s]," when they enter into larger discourses. To be clear, my specific site for exploring this perspective is that of Polish-immigrant Chicago, but the relationship between space and discourse that I am describing here should be understood as a much broader theoretical claim that can be found in various contexts.

I will look at only a few of the many historical and present-day spaces of Polish Chicago, drawing on both textual and ethnographic data. Specifically, I have organized the next sections of the paper around three spaces, according to their metonymic operations: 1) Stanistawowo-Trójcowo: Space as Community; 2) 
Jackowo: Space as the Horizon of Immigrant Life; and 3) Polish Suburbia: Space as Upward Mobility. In some ways, each space carries a unique story, but all of the spaces participate in a larger historical narrative of the progressive movement of Poles out from the "urban enclaves" of central Chicago, to city neighborhoods further afield, and, more recently, to the suburbs, or "ethnoburbs," geographer Wei Li's term for multicultural and multiethnic suburban areas where no specific group has a majority but where several groups develop strong community presence (29). This narrative of collective migration is a key thread of these three specific stories, but all of these sites also help illustrate how the interaction of discourse and space help construct everyday community experience.

\section{Stanisławowo-Trójcowo: Space as Community}

The area of Chicago once known by Poles as Stanistawowo, or StanistawowoTrójcowo, and then later as "Polish Downtown" and "Little Poland," is where Polish immigrants first set up a community in the $19^{\text {th }}$ century and remained dominant for more than 50 years. The area is part of Chicago's official West Town community area (or more colloquially, Noble Square), but it is known today by many Poles as Polski Trójkąt (the Polish Triangle), a reference to the triangular concrete island at the intersection of Ashland, Milwaukee, and Division streets. What I see in the story of this area is an example of how urban space can stand in for the idea of community itself, and, also, how the material productions of that space, as planning and building, can enter everyday discourse. This is almost exclusively a story of the past, so my sources here are historical texts. In the next two sections of the paper, I will draw more directly on my ethnographic work with present-day immigrants.

According to multiple accounts, the first Polish immigrant to Chicago was Captain John Napieralski, who arrived in 1837. However, a Pole named Anthony Smarzewski-Schermann, who came in 1850, is credited as the founder of the Chicago Polish community. He opened a grocery store on Noble and Bradley, a few miles northwest of Chicago's downtown Loop, and changed his name to Schermann in order to do business with Germans in the area. But he remained most closely connected to the Polish community (Parot 19-20). Along with other Poles, he formed the Society of St. Stanislaus Kostka in 1864, which in 1881 accomplished its goal of building a grand church, the St. Stanislaus Kostka cathedral (Kościót św. Stanisława Kostki), or simply "St. Stanislaus." This church, the largest Polish church in America for many years (Parot 23) and one of the largest Catholic parishes in the world for a time (Kantowicz 31), became the cornerstone of the community, which is why Poles started referring to the neighborhood as Stanisławowo (which translates loosely as "the Stanislaus neighborhood"). This is a very direct example of how early Polish immigrants used urban space to develop their own community discourse. Indeed, according to one view, the high-reaching St. Stanislaus cathedral was specifically designed to "dominate" the neighborhood skyline as "a testament to the dominance" of the group who built it (Parot 65). ${ }^{3}$ However, this church was soon met with the construction of a competing Polish church just a few blocks away. 
The Holy Trinity cathedral (Kościót Świętej Trójcy, or Trójcowo as it is known by Poles), was built by a group called the Gmina Polska (the "Polish Commune"), which was formed shortly after the St. Stanislaus Kostka Society in order to offer an alternative, more nationally oriented community than the one promoted by the strongly clerical St. Stanislaus group (Parot 28-29). This rivalry between Catholic and nationalist factions carried on for several decades in Chicago, and the Stanisławowo area later came to be known as Stanisławowo-Trójcowo to account for both groups and parishes. Thus, these two large churches, both of which still stand a few blocks apart in Chicago's West Town neighborhood, were very material manifestations of this ideological struggle that was central to the community. Or, to borrow Ornatowski's language, the churches "figured forth" specific ideological worlds - one Polish Catholic, one Polish nationalist-into urban space. In addition to the churches, the two groups built numerous other structures to assert their dominance. Their competing fraternal organizations, the Polish Roman Catholic Union (formed by the clerical group in 1874) and the Polish National Alliance (formed by the nationalists in 1880), both built large edifices for their headquarters. Additionally, each group supported daily newspapers and other publications, all of which were housed in grand structures no more than a few blocks from the churches. In all, Polish Downtown quickly became marked by ideological spatial discourses, which, by their mere presence, actively participated in everyday community experience.

These material signifiers held specific intra-group meanings for the local audience of Polish immigrants. However, for the broader audience of Chicago residents in those years, the two grand churches, along with their accompanying organizational, educational, and press buildings, made an argument for Polish presence in the context of an increasingly multiethnic Chicago. More specifically, during the years when most of these buildings went up, between 1880 and 1920, about 2.5 million immigrants came to Chicago, including large numbers of Poles, Bohemians, Russians, and Italians (Spinney 123-126). While some of these communities formed ties with other groups in order to build broad political power, Poles typically refused to bargain with others, favoring in-group alliances. One effect of this behavior was that Poles had limited political success, because their candidates could never garner broad support (Spinney 129); however, another result was an exceptional degree of community solidarity. Thus, within the broader discursive world of immigrant Chicago, the numerous buildings of Polish Downtown became a metonym for collective Polish strength.

This was the spatial discourse of the Polish Triangle in its historical context. At the present moment, the buildings, as signifiers, do not seem to participate in the same argument of community solidarity. While the St. Stanislaus and Holy Trinity churches prominently line the I-90 Kennedy Expressway, and the Polish flag flies daily over the Polish Roman Catholic Union headquarters, their argument is historical, if not anachronistic. This is partly a question of demographics. According to census data, the number of Poles in the West Town community area has decreased steadily since 1930, when there were almost 37,000 foreign-born Poles (which accounted for $54 \%$ of all immigrants in the area) (Wirth and Bernert "West Town”); 
to 1970, when there were fewer than 8,000 Poles (Community Area Data Book); on up to 2000, when fewer than 3,000 Polish immigrants remained (The Polish Community). As one observer in the 1970s put it, the Polish Triangle was already considered by many to be "the old ghetto hub" (Emmons 95). But beyond demographics, the argument made by the built world of Polish Downtown is historical because it stands in for, or "reduces," an ideological construction that probably no one would claim exists today - that of a spatially defined community of Polish immigrants. Indeed, the diminishing number of Poles in the West Town area since the 1930s is a direct result of the community's gradual and collective migration out from the central neighborhoods into spaces on Chicago's northwest side. One such area is the Avondale community area, or Jackowo, as it is known to Poles. ${ }^{4}$

\section{Jackowo: Space as the Horizon of Immigrant Life}

If the space of the Polish Downtown once served as a metonym for community solidarity, then the area of Avondale/Jackowo now functions metonymically as "the horizon of immigrant life" within Polish rhetorics. How this "horizon" operates, and what it suggests about the identity of Polish Chicago will be my primary concerns here. In short, the Jackowo neighborhood, as a discourse, illuminates the way that immigrants can invest urban space with paradoxical meanings of sociocultural belonging and socioeconomic limitation, and the way that these meanings can then gain currency within community rhetorics of self-definition. As demographer Audrey Singer has described immigrants' urban enclaves, they have both "positive" and "negative" connotations: they offer new immigrants "support, familiarity, and linguistic and cultural ease," but they are also typically thought of as "isolated areas" that "restrict the incorporation of immigrants into the mainstream" (5). In my analysis, Jackowo exemplifies these dual meanings for Poles, and for these reasons it is a uniquely powerful signifier.

As Poles have defined it for me, and as my own experiences in the neighborhood suggest, Jackowo is centered around the intersection of Milwaukee and Belmont Avenues, and expands out from that point for a few blocks in every direction. The area already had its first Polish inhabitants by the end of the $19^{\text {th }}$ century, when small groups of Poles began moving the few miles northwest from Polish Downtown. Indeed, the St. Hyacinth Basilica was actually founded in 1894 by Poles from the St. Stanislaus cathedral group (Parot 235). By World War I, Jackowo was part of a "Polish Corridor" along Milwaukee Avenue, which connected the original 1860s settlement to neighborhoods further out from central Chicago (Parot 75). Indeed, more generally, the largest outward migration of Poles more or less followed the path of Milwaukee Avenue from the $19^{\text {th }}$ century and well into the $20^{\text {th }}$, as the maps in Figure 2 show. According to 1930 and 1940 census data, Poles constituted the top group of foreign-born inhabitants in the Avondale area during those years (Wirth and Bernert "Avondale"), and from about the 1970s through the 1990s, Jackowo was a locus for Polish immigrant life, even if its status never rivaled the 


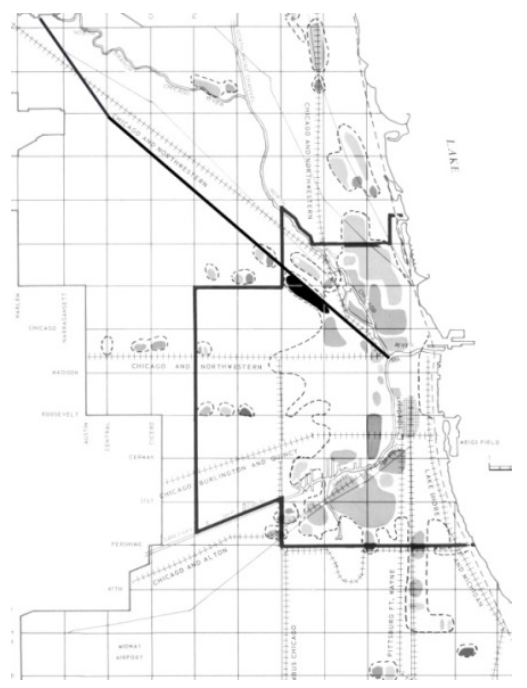

1870

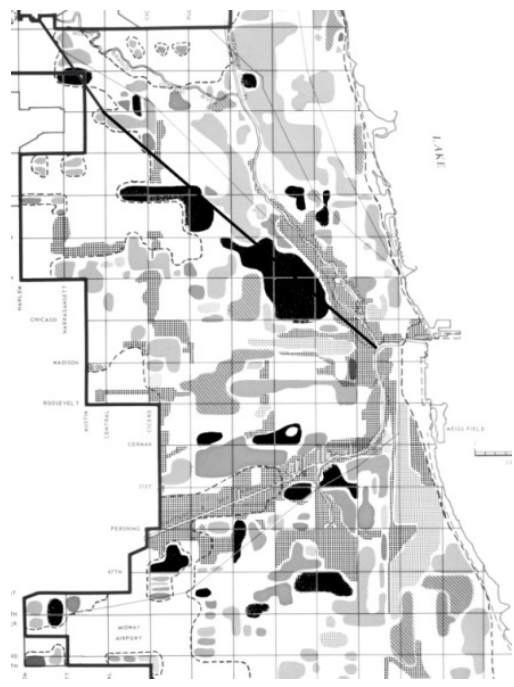

1920

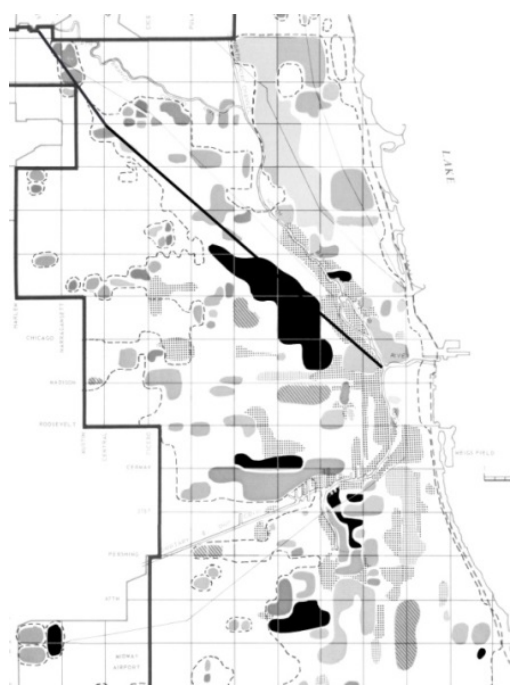

1900

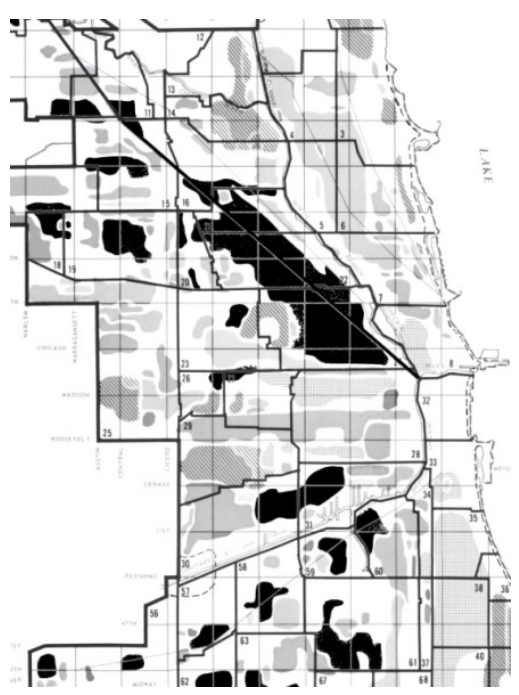

1950

Fig. 2 - These City of Chicago “Settlement Maps" show the movements of several ethnic groups. I have highlighted the Polish settlement areas in black. (On the original maps, the areas that appear as various shades of gray here are multiple colors, designating different ethnic groups.) I have also darkened the northwest corridor of Milwaukee Avenue to emphasize the relationship between that street and the general path of Polish settlement. 
historical status of Polish Downtown. When sociologist Mary Patrice Erdmans surveyed businesses on Milwaukee Avenue between Belmont and Diversey Avenues in 1989, she found that $40 \%$ of the owners were Polish immigrants and $22 \%$ were Polish-Americans. Furthermore, 90\% of the customers were Polish immigrants or Polish-Americans (78). As many Poles have reported to me, the name Jackowo itself also had strong currency in Poland during the communist years and even into the 1990s, serving as a metonym for Polish life in Chicago, or perhaps even for Polish life in the U.S. (The only other rival for that status might be the Brooklyn, NY, neighborhood of Greenpoint, which also had a very high Polish immigrant population during those years.) Despite on-going demographic changes in the area, as large numbers of Latinos have moved in and some Poles have moved out - often for the suburbs - the blocks around Milwaukee and Belmont Avenues are still populated by Polish immigrants. In many cases, these are new arrivals who can find cheap housing in Jackowo, sometimes in shared rooms with other Poles who are also new to Chicago, and perhaps even in ground-floor apartments. These particular apartments are known among Chicago Poles as bejsmenty-a loan-word from "basements"- which functions as a popular metaphor for the dismal material conditions that often constitute the first years of immigrant life. Polish shops, delis, restaurants, and bakeries also dot the area, amidst a growing number of Latino establishments (see Fig. 3).

What emerges from these aspects of the space of Jackowo is, on the one hand, a clear spatial rhetoric of Polish community, not unlike that which I described for historical Polish Downtown. It is a place where Polish immigrants can experience a comfortable life by buying familiar products (imported from Poland), encountering Poles in public spaces, and, most importantly for many, carrying out daily life in the Polish language. For example, a woman who lived with her family in Jackowo for the first years of her immigration in the mid-1990s described it to me this way: "For people like us who had just arrived, it was good because everything was in Polish... There were Polish stores, a Polish church, Polish businesses... I think for new arrivals who don't speak English it's a great place to live-where you really feel like you're in your own kind of comfortable place... Like in Poland." In the context of a rhetoric like this, the "horizon of immigrant life" suggested metonymically by Jackowo can be positive, in that it circumscribes a space of sociocultural comfort and belonging, where a Polish immigrant can live "like in Poland."

But Jackowo's rhetorical "horizon" is also a limiting factor to socioeconomic mobility. As noted, the area is in many cases a "first-stop" neighborhood for Polish immigrants. I have talked to more than a few Poles who have lived in the Chicagoarea for several years who either resided or worked in Jackowo for the initial period of immigration. But they moved out with time either because they wanted to escape the perceived negative features of the area-including, in the narrative of at least one woman, the influx of Latinos — or because they desired the more expansive spaces offered by the suburbs (which is the focus of the next section of this paper). One particular feature of the space of Jackowo that seems to concretize this metonymic "horizon" of socioeconomic mobility is the sidewalk in front of a gas station at the 

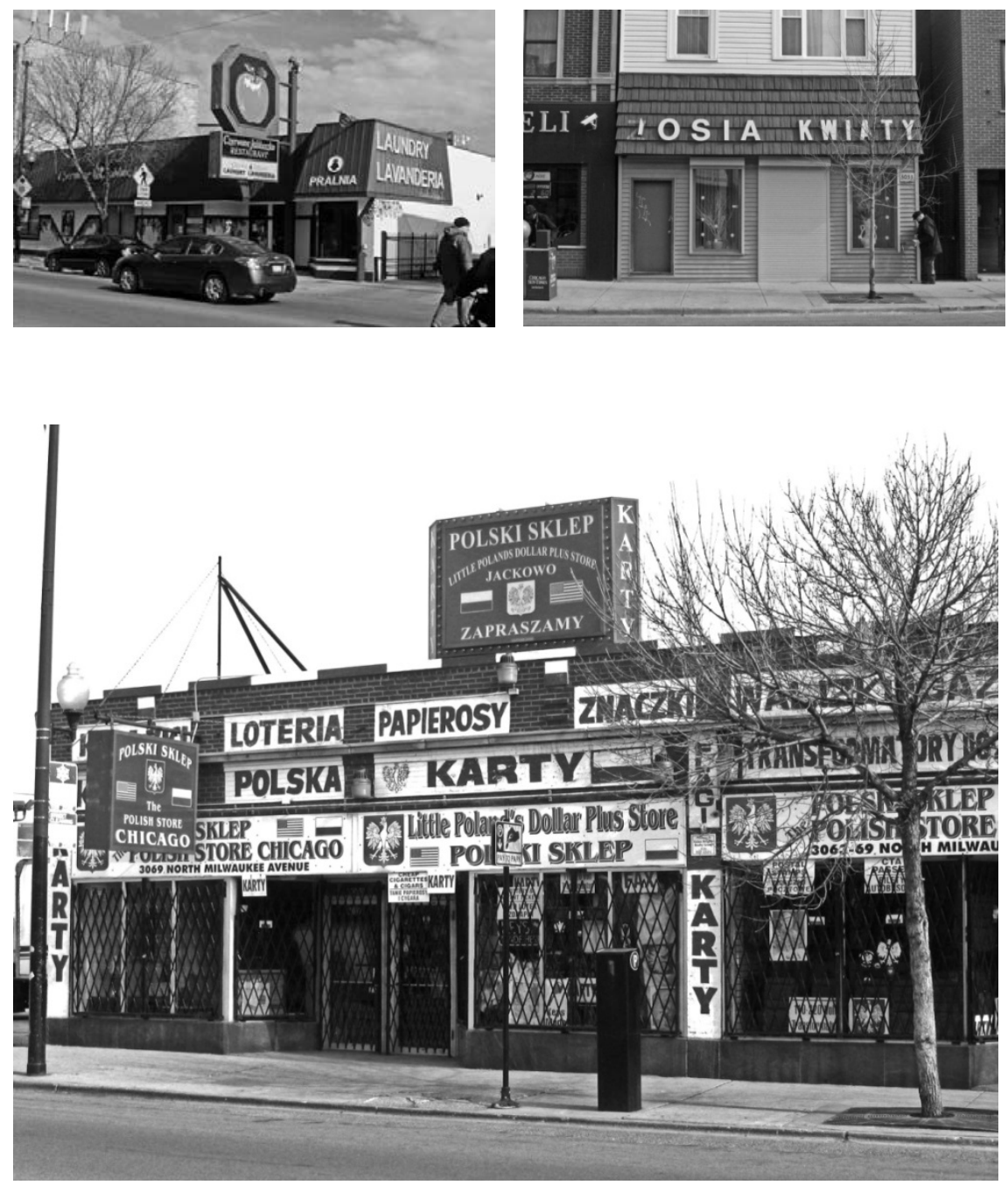

Fig. 3 - The top left picture shows the Czerwone Jabluszko Restaurant ("The Red Apple"), a long-standing Jackowo institution that offers an all-you-can-eat buffet of Polish fare. It is attached to a laundromat that is labeled in English, Polish, and Spanish. The top-right picture shows the aging storefront of Zosia Kwiaty ("Zosia Flowers"). The bottom picture shows the Polski Sklep ("The Polish Store," or perhaps "Little Poland's Dollar Plus Store" as the sign above the door would have it). Inside one can buy numerous products with Poland's colors (white and red) and the Polish white eagle insignia. The store also sells telephone cards, cigarettes, and stamps. All photographs by the author.

corner of Milwaukee and Belmont Avenues, which is the epicenter of Jackowo. This is the site where male immigrant day-laborers stand in the mornings waiting to be picked up by contractors and others who need short-term employees. Polish men wait together with men from other post-communist countries, as well as with Latinos and other immigrants. These kinds of day-laborer pick-up spots are a familiar 
feature of immigrant life all over the U.S., and they are an especially important aspect of the labor market for the undocumented (see Valenzuela, and Valenzuela et al). Standing on the corner waiting for work is seen by many Poles with whom I have spoken as a kind of bottom rung of socioeconomic existence. This is not because manual labor is perceived negatively - it is not, as many Poles I know carry out manual labor now, and almost all have done so at some point or another during their immigrant experience-but rather because of the demeaning and insecure nature of standing on a street corner waiting for work. To this extent, then, the presence of the day laborers on the sidewalk seems to perfectly encapsulate Jackowo's socioeconomic "horizon" in the larger discursive world of Polish Chicago. As one Chicago-Polish businessman put it in a 2009 interview for Polityka, a prominent news magazine from Poland, "Jackowo is our Ellis Island. ... Polish Milwaukee [Avenue] in Chicago is a transitional camp, continually strengthened by new escapees from Poland. Many get out as soon as they become independent" ("PGR Jackowo”). Thus, Jackowo, both as an urban neighborhood and a discourse, signifies an outer limit of both community inclusion and socioeconomic possibility. But this double meaning not only reveals something about the experience of Chicago Poles, and, for that matter, of many other immigrants, who also struggle with the paradoxical horizons of sociocultural belonging and socioeconomic limitation; it also enters into that experience as a metonym. Indeed, the name Jackowo itself allows Poles to position themselves vis-à-vis community identity. One can use it derisively, as I have heard done many times, to distance oneself from the perceived negative features of the community, or one can use it positively, as the woman from my fieldwork did, to express a need or appreciation for a sense of Polish community solidarity in the complex, multiethnic world of Chicago. Either way, the urban space around Milwaukee and Belmont Avenues becomes a participant in the construction and negotiation of community ideologies.

It is important to note that Jackowo is not the only Polish neighborhood in the city of Chicago today, nor is it, statistically speaking, the most Polish. The area of Portage Park, which is the location of the church basement from my earlier ethnographic scenes, is home to the most Chicago Poles right now, followed by other northwest side neighborhoods and a few areas on the southwest side. These neighborhoods also offer a kind of "horizon of immigrant life," like Jackowo, although they do not seem to be perceived quite as negatively as that area. In all cases, however, these city neighborhoods seem to be gaining an increasingly negative perception among Chicago Poles, and the clear demographic trend is large-scale migration to the suburbs. In my analysis, this kind of suburban re-location is generally understood by Poles as a necessary aspect of upward mobility.

\section{Polish Suburbia: Space as Upward Mobility}

There are now many more Polish immigrants in Chicago's suburbs than in the city itself. According to the U.S. Census Bureau's estimates for 2009, there were 
about 96,000 Polish immigrants in the suburbs and 46,000 in Chicago itself. This is a dramatic change even since 2000, when there were 70,000 Polish immigrants in the city and 69,000 in the suburbs. What interests me most about this collective migration is the question of how the new suburban spaces are entering into community discourses and ideologies. In short, what I see in this particular story is, on the one hand, an example of how geographical space can be filled with a group's socioeconomic dreams and aspirations, but also, on the other hand, an example of how a space itself, in its very material features, can expand a community's discursive resources.

Although the high number of city-to-suburb moves in recent years is striking, Poles have in fact been moving to Chicago-area suburbs for more than a century. For example, during the final decades of the $19^{\text {th }}$ century, when some groups of Poles were setting up new communities in city neighborhoods a few miles north and west of Polish Downtown, others were moving outside the city limits altogether to suburbs such as Lemont, South Chicago, Cicero, and West Hammond (Bigott 113). In the case of West Hammond, 234 Polish families settled in a development called Sobieski Park between 1891 and 1900. This area was marketed specifically to Poles, and a community parish was included as part of the original planning (Biggott 149157). This immigrant pattern of settling first in city neighborhoods and then later in suburban areas is not unique to Poles; indeed, this model has defined immigrant habitation patterns for many decades, as immigrants, like all other groups, have historically moved out to the suburbs as they have become more affluent (Bruegmann 29). More recently, however, demographers have shown that the pattern is shifting, as many new immigrants to the U.S. are bypassing the cities altogether and settling directly in the suburbs, due both to established social networks and to the global restructuring of the economy, which has moved many job opportunities to suburban areas. Indeed, by 2005, almost twice as many immigrants were living in American suburbs as in cities, compared to a nearly equal number in both places in 1990 (Singer 15). In the analysis of Susan Hardwick, this is transforming the U.S. into a "suburban immigrant nation" ("Towards a Suburban Immigrant Nation" 31). These numbers are partly a reflection of the fact that immigrants are now arriving in metropolitan areas that were not traditionally hubs for new immigrants—such as Phoenix, Atlanta, Charlotte, and Austin —and many of these areas are "loosely bounded, lower density, sprawling, automobile-dependent metropolitan areas" where the large majority of residents—immigrants or not—live outside the city limits (Singer 15). But the same phenomenon is also occurring in cities that have long histories of immigration, including Chicago. In the case of Chicago's northern suburbs, for example, where many Poles live, a recent report estimates that as many as 35,000 new immigrants have moved directly to those areas since 2000 (Open to All? i). One result of these changes is the development of Wei Li's "ethnoburbs." As she understands them, ethnoburbs share certain features with traditional urban enclaves-including a strong presence of ethnic stores, businesses, social networks, and religious groups - but they are "more open to the mainstream society" (47) and allow members of the ethnic group to integrate into that society through "economic activities, political involvement, and community life" (4). 
Undoubtedly, Li's description of ethnoburbs captures the situation of Poles in certain suburban areas, where it is quite easy to find Polish stores and businesses, as well as Catholic churches that offer Polish masses; but where there are multi-ethnic communities, and where the large majority of residents are not Polish. Thus, to borrow the language of the woman who told me she had enjoyed living in Jackowo during her first years of immigration because she and her family could live "like in Poland," it now seems to be the case that a Pole can also live "like in Poland" in several areas outside the city.

In terms of Poles' motivations to move to the suburbs, the situation may not be very exceptional. As one critic of American suburbanization, J. John Palen, describes suburbs, they are much more than simply "a geographical location," or "various collections of certain types of residences," or "the abodes of certain types of people"; rather they are "an idea," which, in post-WWII America, melded together with ideologies of "the American Dream" and the possibility of "new forms of community" (68-92). These broad depictions of the suburban imaginary also help explain Polish immigrants' suburban desires, because the popularly understood Polish-immigrant “American Dream” includes a singlefamily home, privately owned outside space, and family cars in the driveway. Indeed, the mythic photograph that a Polish immigrant sends back to family in the homeland is a proud portrait in front of a car and a detached house. However, in my own understanding of Polish immigrants' rhetorics and socioeconomic ideologies, suburban space embodies more specialized meanings as a result of at least two unique factors: the desire to distance oneself from the traditional urban enclaves and the historical experience of space in communist and postcommunist Poland.

As described earlier, Jackowo, in particular, and Portage Park and other city neighborhoods to a lesser degree, function as "horizons" of socioeconomic possibility — and by moving to the suburbs, Chicago Poles can distant themselves from this horizon, both literally and metaphorically. For example, in the language of one man from my fieldwork who lived in Jackowo for his first years of immigration but now lives in a suburb, the physical space of Jackowo itself seemed to convey limitation. He described his first days in Chicago in this way: "[T]he first impression you get when you come to the city, you see how Chicago looks-the ugliness knocks you over. Downtown is fucking awesome. It's fantastic. But when you're just functioning normally_you're going up Milwaukee [Avenue]—it's the fall, and so on, and you look at those buildings, how they look. There's something oppressive, dangerous, negative." He went on to talk about the "cheap, dirty" look of the businesses in Jackowo as especially offensive: "There was something about it that made it so it was unusually difficult to like this place." This is one particular, though not at all unique, way of figuring the aesthetic undesirability of Jackowo. But there is also a social dimension to the Polish urban neighborhood that circulates as a commonplace among Chicago Poles-albeit one that people have rarely articulated to me explicitly. In the case of Jackowo, the perceptions that many of the residents are newer arrivals who may be living with compatriots in basement rental units, who 
may stand on the street corner waiting for work, and who may not speak English well, all help to construct the area as socially undesirable-at least for those who have the possibility of living elsewhere. In contrast to this social milieu, the suburbs, and specifically some of the Polish ethnoburbs on the north and northwest sides of Chicago, offer a chance to live among middle-class Americans and immigrants from other countries, and to somehow be, or at least feel, “American.” In a sense, a Polish immigrant living in an ethnoburb can experience his or her own Polish identity selectively. That is, if one wants to go to a Polish store or business, attend Polish mass, or simply interact with other Poles, the options are always there; on the other hand, if one wants to inhabit "American” spaces and interact with Americans, or members of other immigrant groups, those options are there, too. In these ways, suburban space offers Poles a new kind of discursive and cultural resource-a perceived control over one's own identity formation.

One suburban Pole described a version of this to me when she talked about her limited relations with other Polish immigrants who live in the same condominium complex: she has heard parents calling out in Polish to playing children; she has passed by groups of Poles speaking to one another; and once she even helped an older Polish woman carrying grocery bags in the ice and snow-but she has no intimate contact with any of these people, and as far as she's concerned, this is not a problem. As she put it, "[t]he thing is that there's just no time to meet together and talk... It seems like if the chance comes up, we'll talk. That's it. But I'm not going to go around and knock on doors, and say 'Oh, you're a Pole? I'm a Pole, too.”' She did tell me, however, that she has Polish friends in the suburbs, and she has a Polish church not far away. She also noted that her mother's condominium complex —in a nearby Polish ethnoburb_features a community pool where Polish immigrants congregate and strike up new friendships. Thus, she seems to enjoy the freedom to be, or not be, "Polish," according to her personal wishes. This is a stark contrast to living in an area like Jackowo or Portage Park, where it is nearly impossible to escape the omnipresence of "Polishness."

This woman's description of living in a Polish ethnoburb also highlights the very materiality of suburban space, and, in particular, its vastness. This quality, at least partly, allows the suburbs to stand in for "upward mobility" within community rhetorics, to the extent that a Pole can improve the perception of socioeconomic status by being less "Polish"_-or, at least, of being less like Polish immigrants who live in the urban enclaves, might not speak much English, and do not have steady work. This geographical vastness also points to a key difference between the experience of space in an American suburb and the experience of space in communist and post-communist Poland, an experience that all Polish immigrants share. In the case of this particular woman, she says that part of the reason she's been able to maintain distance from Polish neighbors is because they simply do not share space: "It's not like we're riding the same bus to work because everyone has their own car. It's not like we see each other in the line to buy meat because there are no lines to buy meat.” These two specific examples are actually quite telling. It was not easy to own a car in communist Poland, and the experience of waiting in line to buy meator to buy any groceries — was a dominant aspect of everyday life in the People's 
Republic of Poland, especially in the late 1970s and early 80s, when meat and other products were sold on ration cards, and when one sometimes had to wait in line for several hours to make such purchases. Thus, whereas the political and economic circumstances in communist Poland seemed to force social interaction-or at least social proximity - the reality of the American suburb almost precludes such unplanned encounters with strangers, or, more ideologically, with one's own "Polishness." With regard to this woman's specific examples, the situation is certainly very different in post-communist Poland, where there are no more long lines to buy meat, and where exponentially more people own cars than they did in the 1980s when she was a child. However, even if the experience of public space in post-communist Poland has changed since the 1989 political transformation, the experience of private space-and more specifically of residential space-has changed much less.

The residential buildings that went up in communist Poland, like in all other parts of communist Europe, were mostly concrete-slab towers, typically organized into communities of several such buildings called osiedle ("settlements"), which are located on the outskirts of both large and small cities throughout Poland. According to architectural historian Andrzej Basista, more than 4 million apartments were built in the People's Republic of Poland, and most of them were in such multi-unit buildings, or "blocks"; furthermore, he estimates that in 2000 more than $20 \%$ of Poles were living in block settlements, with the percentage reaching 65\% in large cities such as Krakow, Poznań, and Gdańsk, and going even higher in cities that were largely destroyed during World War II, such as Warsaw and Szczecin (120). Despite the utopian, socialist visions of community life that drove the planning of block settlements - which exemplify Ornatowski's thesis on the ways that communist state discourse shaped the built world of post-war Polandthese developments had, and continue to have, multiple problems, and are typically considered the least desirable places to live for Poles. All seem to agree that they are an aesthetic blight on the country, and, in more recent years, block settlements in the large cities have gained notoriety in the popular imagination as centers of youth criminal activity. More than all of this, however, Poles' primary complaint about life in block towers is the limited living space. As geographer David Crowley describes the situation in post-war Warsaw, plans for the building of private residential spaces were always secondary to large projects that would enter the "public's gaze,” and, as he puts, it, “[s]pace was a resource to be apportioned like any other in the command economy” (202). Indeed, even by the mid-1980s, in the final years of communism, the average square footage of publicly built apartments in Polish urban areas was only 581 sq. feet (Basista Annex 4, Table 8).

This shared experience of cramped residential space in Poland provides more context for "the suburbs" as a powerful signifier in Polish immigrant discourses. That is, the vast spaces of the suburbs allow, as mentioned before, an escape from the urban enclaves and, potentially, from unplanned, day-to-day interaction with other Poles; additionally, though, they offer a dramatic 
counterpoint to the past experience of living space in Poland. Thus, one climbs the socioeconomic ladder both by getting far away from the traditional immigrant neighborhoods of Chicago and by entering a spatial realm that is remarkably different than, and even "better than," that of post-communist Poland. ${ }^{5}$ One man set up this distinction for me directly when he compared the apartment he and his wife had owned in city of Rzeszów in the 1990s to their condo in a Chicago suburb. Their place in Poland was over a busy, noisy, smelly street, and the limited space-about 500 sq. feet-was divided into four small rooms. They had family in a village not far away, but the standard of living there was much lower, as there were no sewers, only outhouses. For him, the defining feature of his American life is freedom of movement: "the possibility of - the freedom to move around, of transportation. The fact that you can have a car, and that gasoline is affordable changes a lot.” In his case, it allows him to live in a quiet area, where he can see trees out the back window, and where he finds the neighbors - some Polish, some not-very agreeable. As I understand it, these aspects of American suburban space all play a key role in this particular man's personal discourse of upward mobility.

\section{Places Beyond}

I opened with two vignettes involving immigrant rights activists and maps in the basement of a church in Portage Park. To close, I want to offer another map scene, one that provides a move beyond the spaces of Polish Chicago and into world spaces, which are also a distinct dimension of all immigrant discourses. This scene took place in the suburban condo of the man I was just describing, a man I'll call Jan here, who interprets his own American life in terms of "freedom.” When I was visiting Jan's home one day, he told me about his experience of living and working on a small farm in England in the summer of 1997, before he moved permanently to the U.S. As he talked to me about the farm, he decided to look for the website to show me some pictures. In the process, he discovered that he could view the whole farm in precise detail on Google Earth. As we looked at the buildings and hop fields, at a bridge and a windmill, at the old farm house where the owner lived, and at the dirt road where Jan's friend had once lost control of his bike and gone flying through the air "like Adam Małysz," the famous Polish ski jumper, Jan's sense of awe at viewing the farm was palpable: "Incredible... This is just unbelievable... Holy shit..." As we talked on, he told me about how much he'd enjoyed living on the farm and about the beauty of the rural landscape itself, which on foggy moonlit nights "looked like it was from a different world." The description of this place contrasted with some of the other conversations Jan and I had been having that day, when he'd told me about recent frustrations with his own situation, since he lives in the U.S. without papers. Thus, as I understood them, those spaces of the English farm, which existed for Jan that day by way of a digital discourse, had deep currency in his personal imaginary. In terms of the kind of discourse-place relationship I have been exploring throughout this article, Jan's experience of actually living on that farm, and then later his virtual experience of that farm via the representations of Google Earth, inserted that rural 
space into his present discursive world, primarily as a signifier of how life could be better for him than it was at that moment.

This example of Jan highlights, at least partly, how digital experience may be altering our interaction with space, a shift that David Harvey and others have famously described as a "time-space compression." However, for me, it also reveals something about our evolving relationship with proximity, which links up very directly to my broader observations about Chicago Poles, discourse, and space. As I see it, the narrative of this group's gradual movements out from urban enclaves to the suburbs can also be read as a story about evolving interpretations of "community." In the early years of the community's development, there was a clear desire to claim city spaces as "Polish," as the grand buildings of the Polish Triangle demonstrate, and a version of this desire continues today for some Poles, who still appreciate the very literal proximity to "Polishness" offered by urban enclave neighborhoods like Jackowo. However, as jobs move to the suburbs, and as recent Polish immigrants work to ascend the socioeconomic ladder, these traditional community spaces strike many as unnecessary or even undesirable. Quite simply, while the large majority of Poles whom I know still maintain strong ties with compatriots and the wider Polish-immigrant community, many now seem to prefer the more selective version of community experience that they can find in an ethnoburb. For them, sheer proximity to other Poles and the experience of shared urban space are not required. To what extent this shift might be a manifestation of "time-space compression," and the ways in which the Internet may be diminishing our desire for communities of human proximity, is beyond the scope of my work here. It is, though, a question of human geography that reaches far beyond the world of Polish immigrants, and even beyond immigrant groups in general. However, what both the scene with Jan and the larger story of the spaces of Polish Chicago make clear to me is that our relationship to space and community, as everyday experience and as rhetorical invention, is undergoing a profound transformation.

In the perspective of Doreen Massey, the kinds of developments I am trying to describe here open up the possibility of a newly "progressive" spatial thinking, one that does not necessarily connect specific spaces to specific community identities. As she sees it, “...communities can exist without being in the same placefrom networks of friends with life interests, to major religions, ethnic or political communities” (153). Thus, for her, the spaces of everyday life are always linked to "places beyond" (156). The desire for such "places beyond" has clearly inspired Polish immigrants' on-going re-locations, and, more broadly, everyday spaces can only become "places beyond" through an on-going interaction with ideology and discourse. An investigation of the relationship between discourse and these kinds of unbounded spaces_-which include both literal global spaces and more imaginary spaces of digital experience-may be the next logical step beyond the very placespecific analysis that I have offered here. 


\section{Jason Schneider}

Jason Schneider is Visiting Assistant Professor in the Department of Writing, Rhetoric, \& Discourse at DePaul University in Chicago. He also coordinates DePaul's Graduate Certificate in TESOL. In addition to his ethnographic work on Polish Chicago, Dr. Schneider writes about issues connected to the teaching of college writing, applied linguistics/TESOL, and the rhetorics of popular culture. This article is adapted from a chapter of his dissertation, Inventing Home: Movement, Place, and the Rhetorics of Polish Chicago.

\section{Notes}

1 Some of my other activities with this organization included participating in city-wide political rallies and marches, planning and leading educational workshops on immigration law for members of the Chicago Polish community, designing programming for local Polish media outlets, and organizing public forums involving local politicians. In addition to this aspect of my ethnographic research, I interacted with other members of the Polish immigrant community in a range of contexts. Generally speaking, most of my research participants had immigrated to the U.S. in the late 1990s and early 2000s, and their personal and legal situations varied greatly - which is to say, at least in part, that I worked with both documented and undocumented Poles. I should also note that all of my fieldwork was carried out in Polish, which I speak and read fluently, so the quotations included in this paper are in fact my own translations. Also, any names are pseudonyms.

2 By using the term of "invention" here I am drawing directly on rhetorical theory, and particularly ancient rhetorical theory, in which invention had prime importance. How this concept operates, exactly, in various theories of rhetoric is beyond my scope here; rather, I will only say that "invention" describes the systems and mechanisms by which rhetors discover arguments, a process that invariably demands engagement with a broad range of factors, including audience, goals, and community beliefs. To this extent, then, the term captures the way in which Polish immigrant rhetorics of space have emerged in response to a wide array of social, political, and economic forces.

3 The unique importance of church-building in the early decades of Polish settlement in Chicago has been noted by historians. Indeed, one of the first organizing activities of newly situated Poles was building a community parish (Kantowicz 15). This church always had a broad role, serving as "community center" (Kantowicz 30) and as the "social, economic, and often political center of the neighborhood," much like the village church in $19^{\text {th }}$-century rural Poland (Pacyga 126-127). As one Polish Chicago priest of the time put it, "The Polish Catholic who doesn't belong to any parish is homeless - without support, religious or national, he is a social bankrupt, a bandit on the open highway, and sooner or later he must perish because without support he will not be able to meet the test" (qtd. in Bigott 111). The importance of churches is certainly not unique to the history of Poles in America. For example, in 
The Madonna of $115^{\text {th }}$ Street, Robert Orsi explores how the Church of Our Lady of Mount Carmel, and an annual festa of the Madonna associated with it, were central to the construction of community identity and solidarity in Italian Harlem.

4 Jackowo, which is pronounced yäts-ko-vo, means "St. Jack's neighborhood," due to the local St. Hyacinth Basilica. (The name "Jack," or the Polish "Jacek," has the same root as "Hyacinth.”) This process of colloquially re-naming a neighborhood after the local parish's patron saint mirrors what happened with StanisławowoTrójcowo. The practice was not uncommon in Chicago neighborhoods during those years.

5 As noted, the desire for suburban life is not unique to Poles; this has been a hallmark of immigrant groups, as well as other social groups in the U.S., for many decades now. However, it may be that the particular experiences of communist and post-communist landscapes intensify this desire. An interesting parallel to the case of Chicago Poles appears in Susan Hardwick's description of Russian immigrants to Sacramento, CA in the 1980s and 90s. After first settling in downtown areas, many Russians quickly dispersed to suburban areas, as soon as they had the language skills and found employment opportunities ("Russian Acculturation” 266). Hardwick notes that these trends mirror the historical settlement patterns of immigrants, as theorized by Robert Park, Ernest Burgess, and other Chicago School sociologists of the 1920s; however, it is the sheer speed with which Sacramento Russians made these moves that she finds most striking, as a process that might have taken generations for other groups was compressed into a few years (266-267).

\section{Works Cited}

Basista, Andrzej. Betonowe Dziedzictwo: Architektura w Polsce Czasów Komunizmu. Krakow: Wydawnictwo Naukowe PWN, 2001. Print.

Bigott, Joseph B. From Cottage to Bungalow: Houses and the Working Class in

Metropolitan Chicago, 1869-1929. Chicago: University of Chicago Press, 2001. Print.

Bruegmann, Robert. Sprawl: A Compact History. Chicago: University of Chicago Press, 2006. Print.

Burke, Kenneth. Grammar of Motives. Berkeley, CA: University of California Press, 1969. Print.

Community Area Data Book for the City of Chicago: 1970 Census Data by 75 Community Areas. Chicago Association of Commerce and Industry Research and Statistics Department, and Osla Financial Services Corp. Print.

Community Settlement Map for 1870. Map. Chicago: City of Chicago, Department of Development and Planning, 1976.

Community Settlement Map for 1900. Map. Chicago: City of Chicago, Department of Development and Planning, 1976.

Community Settlement Map for 1920. Map. Chicago: City of Chicago, Department of Development and Planning, 1976.

Community Settlement Map for 1950. Map. Chicago: City of Chicago, Department of Development and Planning, 1976. 
Cresswell, Tim. Space: A Short Introduction. Malden, MA: Blackwell Publishing, 2004. Print.

Crowley, David. "Warsaw Interiors: The Public Life of Private Spaces: 1949-65." Socialist Spaces: Sites of Everyday Life in the Eastern Bloc. Eds. David Crowley and Susan E. Reid. New York: Berg, 2002. 181-206.

Dickinson, Greg. “Joe’s Rhetoric: Finding Authenticity at Starbucks.” Rhetoric Society Quarterly 23:4 (2002). 5-27.

- . "Memories for Sale: Nostalgia and the Construction of Identity in Old Pasadena.” Quarterly Journal of Speech 83:1 (1997). 1-27.

Dickinson, Greg, Carole Blair, and Brian L. Ott. "Introduction: Rhetoric/Memory/ Place." Places of Public Memory: The Rhetoric of Museums and Memorials. Eds. Greg Dickinson, Carole Blair, and Brian L. Ott. Tuscaloosa: University of Alabama Press, 2010. 1-56. Print.

Emmons, Charles Frank. Economic and Political Leadership in Chicago's Polonia: Some Sources of Ethnic Persistence and Mobility. Diss. University of Illinois at Chicago, 1971. Ann Arbor: UMI, 1976.

Erdmans, Mary Patrice. Opposite Poles: Immigrants and Ethnics in Polish Chicago 1976-1990. College Park, PA: Penn State University Press, 1998.

Fleming, David. City of Rhetoric: Revitalizing the Public Sphere in Metropolitan America. Albany: SUNY Press, 2008. Print.

Gottdiener, Mark. The Social Production of Urban Space. Austin: University of Texas Press, 1985. Print.

Hardwick, Susan W. "Russian Acculturation in Sacramento.” Geographical Identities of Ethnic America: Race, Space, and Place. Eds. Kate A. Berry and Martha L. Henderson. Reno, NV: University of Nevada Press, 2002. 255-278. Print.

-. “Towards a Suburban Immigrant Nation.” Twenty-First Century Gateways: Immigrant Incorporation in Suburban America. Eds. Audrey Singer, Susan W. Hardwick, Caroline B. Brettell. Washington, D.C.: Brookings Institution Press, 2008. 31-50. Print.

Harvey, David. The Condition of Postmodernity: An Enquiry into the Origins of Cultural Change. New York: Oxford University Press, 1990. Print.

Jack, Jordynn. "Space and Time: Gendered Recollections of Wartime Los Alamos." Rhetoric Society Quarterly 37 (2007): 229-250. Print.

Kantowicz, Edward R. Polish-American Politics in Chicago 1888-1940. Chicago: University of Chicago Press, 1975. Print.

Lefebvre, Henri. The Production of Space. Trans. Donald Nicholsan Smith. Cambridge, Mass.: Blackwell, 1991. Print.

Li, Wei. Ethnoburb: The New Ethnic Community in Urban America. Honolulu: University of Hawaii Press, 2009. Print.

Massey, Doreen. Space, Place, and Gender. Minneapolis: University of Minnesota Press, 1994. Print.

Open to All? Different Cultures, Same Communities: A Look at Immigrant Housing in Chicago's Northern Suburbs. Nathalie P. Vorhees Center for Neighborhood and Community Development, University of Illinois at Chicago. Jan. 2011.

Ornatowski, Cezar M. "Rhetoric and Space: Architecture, Ideology, and the Stalinist Plan for the Reconstruction of Warsaw." Rhetorica: Regina Artis Scientiaeque. Ed. Sławomir Gorzyński. Warsaw: DIG, 2011. 207-224. Print. 
Orsi, Robert Anthony. The Madonna of $115^{\text {th }}$ Street: Faith and Community in Italian Harlem, 1880-1950. New Haven: Yale University Press, 1985. Print.

Palen, John J. The Suburbs. New York: McGraw Hill, 1995. Print.

Parot, Joseph John. Polish Catholics in Chicago, 1850-1920: A Religious History. Dekalb, IL: Northern Illinois University Press, 1981. Print.

"PGR Jackowo: Rozmowa z Jarosławem, Byłym Działaczem Polonijnym, o Nieporadności Polskiego Chicago.” Polityka.com. 29 March 2009. Web. 5 March 2012.

The Polish Community in Metro Chicago: A Community Profile of Strengths and Needs. Polish-American Association. June 2004.

Singer, Audrey. "Twenty-First Century Gateways: An Introduction.” Twenty-First Century Gateways: Immigrant Incorporation in Suburban America. Eds. Audrey Singer, Susan W. Hardwick, Caroline B. Brettell. Washington, D.C.: Brookings Institution Press, 2008. 3-30. Print.

Spinney, Robert G. City of Big Shoulders. Dekalb, IL: Northern Illinois University Press, 2000. Print.

Valenzuela, Abel. “Day Labor Work.” Annual Review of Sociology 29 (2003): 307333. Print.

Valenzuela, Abel, Nik Theodore, Edwin Melendez, and Ana Luz Gonzalez. On the Corner: Day Labor in the United States. UCLA Center for the Study of Urban Poverty. January 2006.

Warf, Barney and Santa Arias. "Introduction: The Reinsertion of Space into the Social Sciences and Humanities.” The Spatial Turn: Interdisciplinary Perspectives. Eds. Barney Warf and Santa Arias. New York: Routledge, 2009. 1-10. Print.

Wirth, Louis and Bernert Eleanor H. (eds.). Local Community Fact Book of Chicago. Chicago: University of Chicago Press, 1949. Print.

Wright, Elizabethada. "Rhetorical Spaces in Memorial Places: The Cemetery as a Rhetorical Memory Space/Place.” Rhetoric Society Quarterly 35:4 (2005): 5181. Print. 
Iowa Journal of Cultural Studies 15 (Spring 2014)

Copyright (C) 2014 by The University of Iowa 